\title{
Effect of Midnight Prayer on Sympathetic Tone
}

\author{
Hadiyatussalamah Pusfa Kencanasari, ${ }^{1}$ Achmad Fauzi Yahya, ${ }^{2}$ Setiawan ${ }^{3}$ \\ ${ }^{1}$ Faculty of Medicine, Universitas Padjadjaran, ${ }^{2}$ Department of Cardiology and Vascular Medicine \\ Faculty of Medicine Universitas Padjadjaran/Dr. Hasan Sadikin General Hospital Bandung \\ ${ }^{3}$ Department of Physiology Faculty of Medicine Universitas Padjadjaran
}

\begin{abstract}
Background: Hypertension is one of the most dangerous ailments which most common risk factor is stress that can activate sympathetic system leading to increased blood pressure. Midnight prayer is believed to calm mind. This study was conducted to discover the effect of midnight prayer on sympathetic tone.

Methods: This cross sectional study was conducted in Bina Siswa Senior High SchoolSMA Plus Cisarua Boarding School, Lembang from October to November 2013. Sixty eight participants were divided into 3 groups based on frequency; high, low, and non midnight prayer. Blood pressure and pulse rate of participants were examined before, during, and after the cold pressor test is taken. Blood pressure and pulse rate duration of recovery were also measured.

Results: This study showed no significant difference between 3 groups in term of systolic blood pressure, diastolic blood pressure, and pulse rate. However, the lowest mean of pulse rate $(64.38 \pm 8.921$ vs $66.69 \pm 11.482$ vs $65.44 \pm 9.584$ respectively), systolic blood pressure [107.19 \pm 6.945 vs $117.13 \pm 13.426$ vs $104.25(75-120)$ respectively], and diastolic blood pressure $[70.38 \pm 7.719$ vs $77.38 \pm 10.935$ vs $70.63 \pm 7.491$ respectively] were obtained in the high midnight prayer group. Recovery duration of blood pressure [6.38 (6-8) vs $6.72(6-11)$ vs $6.75(6-11)$ respectively] and pulse rate $(6.69 \pm 0.946$ vs $7.03 \pm 1.341$ vs $7.00 \pm 1.506$ respectively) among the groups showed no significant difference respectively, however the shortest duration was obtained in the high midnight prayer group.

Conclusions: Midnight prayer has no significant effect on sympathetic tone. [AMJ.2016;3(1):59-63]
\end{abstract}

Keywords: Blood pressure, cold pressor test, midnight prayer, pulse rate, sympathetic tone.

\section{Introduction}

Hypertension is one of the most dangerous conditions especially when it is not controlled. This illness has caused 7.5 million deaths in the world, equal to $12.8 \%$ from total cause of death. ${ }^{1}$ Based on Riset Kesehatan Dasar Badan Penelitian dan Pengembangan Kesehatan 2007, the prevalence of hypertension in Indonesia reaches $31.7 \%{ }^{2}$ One of the most common risk factors of hypertension is stress.

Stress response is the way of human body reacting to stress. Sign of this response is the activation of sympathetic system that will lead to a rise in arterial pressure, bloodstream, cellular metabolism, blood glucose consentration, mental activity, glicolysis, muscle strength, and blood coagulation rate. ${ }^{3}$ When human's body is experiencing stress, physically or mentally, one of body's natural responses which is most measurable is the increased of blood pressure.

Midnight prayer, also known as shalat tahajud or qiyamul lail, is one of the Sunnah prayers (optional prayer) that is believed to be able to affect mental condition. The process of praying (shalat) itself is quite close to a meditation, in addition, there are particular movements and reciting of Al Quran. Regular midnight prayer will calm mind and also leads to lower the risk of stress condition. This calm condition will affect the body when it is stressed, due to the inavoidable nature of stress. ${ }^{4}$ Therefore, theoretically, the risk of hypertension caused by stress can be prevented.

Cold sensation is one of the known physical stressor. This condition can be used to observe the body response by giving the stressor. There is a procedure called cold pressor test that is not only used to know the regulation

Correspondence: Hadiyatussalamah Pusfa Kencanasari, Faculty of Medicine, Universitas Padjadjaran, Jalan Raya Bandung-Sumedang Km.21, Jatinangor, Sumedang, Indonesia, Phone: +6285793110035 Email: hpusfak@gmail.com 
of sympathetic nerve to periphery and coronary circulation ${ }^{5}$ but also can be used as hypertension predictor. $^{6}$ Before conducting the test, blood pressure is measured and this measurement is considered as a base line. The rise in blood pressure of 15/10 $\mathrm{mmHg}$ or more from base line is considered as hyperreactor. ${ }^{5}$ On the other hand, normoreactor is considered if the rise in blood pressure is less than 15/10 $\mathrm{mmHg}$ from base line.

According to this fact, the author see the possibility to discover stress response in someone who have been done midnight prayer regularly compared to those who have not done it. The present study aims to study the effect of midnight prayer to cold pressor test result in Bina Siswa Senior High School (Sekolah Menengah Atas, SMA) Plus Cisarua Boarding School Student, Lembang.

\section{Methods}

This analytical study conducted in cross sectional approach was performed in Bina Siswa SMA Plus Cisarua Boarding School, Lembang, from October to November 2013. This study was approved by the institutional ethics committee and all data regarding patients were concealed.

Fifteen to eighteen years old male participants, had normal BMI, normotensive, healthy, understand about this study, and signed the informed consent were included in this study. Participants who had a history of cardiovascular disease, smoking, drinking alcohol, and open wound on the hand were excluded. Sampling was conducted by total sampling. From those criteria, about 68 out of
144 male students participated in this study.

Participant filled-up the questionnaire about identity, medical history, life style, general condition, and midnight prayer performed within 1 last month. Participants were categorized based on midnight prayer frequency's standard deviation. Participants who had done more than 14 times midnight prayer within 1 last month were considered as high midnight prayer group.Participant who had done midnight prayer 1-14 times within 1 last month were considered as low midnight prayer group, and participants who had never done midnight prayer within 1 last month were considered as non midnight prayer group.

Blood pressure of each participant was measured by mercury sphygmomanometer. After taking rest for five minutes, the blood pressure and pulse rate was measured at the left hand of participants. The right hand of the participant was immersed in ice water (4-10 0C) for 1 minute. Blood pressure and pulse rate were measured at the completion of 1 minute. After that, the participants were asked to remove his hand from the cold water. The particpant's hand was dried up with dry towel and they are allowed to to take a rest. Five minutes after the cold pressor test, blood pressure and pulse rate were noted once more. With 1 minute interval, blood pressure and pulse rate of participants were measured continuously until they reach the baseline.

Data were processed using Microsoft Excel and SPSS 15.0 programme. Proportion of normoreactor data was statistically analyzed using chi square parametric test. The average height of increased blood pressure and pulse rate also the average blood pressure and pulse rate duration of recovery data were analyzed

Table 1 Pulse Rate and Blood Pressure Characteristic of Participant

\begin{tabular}{lcccc}
\hline & Conditions & $\begin{array}{c}\mathbf{P R}^{*} \\
\text { (time/minute) }\end{array}$ & $\begin{array}{c}\text { SBP** } \\
\text { (mmHg) }\end{array}$ & $\begin{array}{c}\text { DBP\# } \\
\text { (mmHg) }\end{array}$ \\
\hline High Midnight Prayer & Baseline & $64.38 \pm 8.921$ & $107.19 \pm 6.945$ & $70.38 \pm 7.719$ \\
(n=16) & Ice water exposure & $66.69 \pm 11.482$ & $117.13 \pm 13.426$ & $77.38 \pm 10.935$ \\
& Recovery & $65.44 \pm 9.584$ & $104.25(75-120)$ & $70.63 \pm 7.491$ \\
Low Midnight prayer & Baseline & $67.25 \pm 8.497$ & $110.64(89-130)$ & $70.31(49-100)$ \\
(n=36) & Ice water exposure & $73.12 \pm 12.139$ & $121.00 \pm 10.918$ & $78.11 \pm 9.748$ \\
& Recovery & $68.61 \pm 9.066$ & $109.33 \pm 11.432$ & $70.33(40-100)$ \\
Non-Midnight Prayer & Baseline & $68.94 \pm 10.976$ & $109.44 \pm 10.046$ & $74.00(49-100)$ \\
(n=16) & Ice water exposure & $74.44 \pm 10.801$ & $122.19 \pm 13.477$ & $81.75 \pm 9.842$ \\
& Recovery & $71.50 \pm 10.640$ & $111.88 \pm 11.200$ & $73.00 \pm 7.127$ \\
\hline Note: ${ }^{* P R}=$ Pulse rate ${ }^{* *}$ SBP $=$ Systolic Blood Pressure
\end{tabular}

Note: ${ }^{*} \mathrm{PR}=$ Pulse rate, ${ }^{* *} \mathrm{SBP}=$ Systolic Blood Pressure, $\#$ DBP $=$ Diastolic Blood Pressure 
Table 2 Proportion of Normoreactor between High Midnight Prayer Group, Low Midnight Prayer Group, and Non-Midnight Prayer Group

\begin{tabular}{llccc}
\hline & & Normoreactor & Hyperreactor & p \\
\hline SBP* & High Midnight prayer & $10(63 \%)$ & $6(37 \%)$ & 0.782 \\
& Low Midnight prayer & $24(72 \%)$ & $10(28 \%)$ & \\
DBP** & Non- Midnight prayer & $11(69 \%)$ & $5(31 \%)$ & \\
& High Midnight prayer & $8(50 \%)$ & $8(50 \%)$ & 0.591 \\
& Low Midnight prayer & $17(65 \%)$ & $19(73 \%)$ & \\
& Non- Midnight prayer & $10(63 \%)$ & $6(37 \%)$ & \\
\hline
\end{tabular}

Note: ${ }^{*}$ SBP $=$ Systolic Blood Pressure, ${ }^{* *}$ DBP = Diastolic Blood Pressure

using one way anova if the data distribution were normal. As an alternative, KruskalWallis non parametric test was also used if the distribution was not normal. Statistically significant was considered when $\mathrm{p} \leq 0,05$. Analysis was performed by comparing those 3 groups.

\section{Results}

From 144 male students, 68 participants fitted to criteria and agreed to be involved in this study. Nineteen participants were considered as high midnight prayer group because they had done more than 10 times midnight prayer within 1 last month, 33 participants were considered as low midnight prayer group because they had done 1-10 times midnight prayer within 1 last month, and 16 participants were considered as non midnight prayer group because they never done midnight prayer within 1 last month. Mean or median of pulse rate, systolic blood pressure, and diastolic blood pressure before, during, and after cold pressor test are shown in Table 1.

Systolic blood pressure (SBP $\mathrm{p}=0.782$ ) and diastolic blood pressure (DBP $\mathrm{p}=0.591$ ) between 3 groups have shown no significant difference (Table 2).

Height of increased SBP and blood pressure duration of recovery data distribution were not normal, therefore the data were analyzed using Kruskal-Wallis Test. The height of increased DBP and pulse rate also the pulse rate duration of recovery were analyzed using One Way Analysis of Variance (ANOVA) because the data distribution were normal. There was no significant difference between the height of increased SBP among those 3 groups ( $\mathrm{p}=0.626$; $95 \%$ Confidence interval, 8.84-12.80). Height of increased DBP ( $p=0.939 ; 95 \%$ Confidence interval, 5.75-9.46) and pulse rate $(p=0.215$;

Table 3 Proportion of Normoreactor between High Midnight Prayer Group, Low Midnight Prayer Group, and Non-Midnight Prayer Group

\begin{tabular}{lcccccc}
\hline & $\begin{array}{c}\text { Median of SBP* } \\
\text { (mmHg) }\end{array}$ & $\mathbf{p}$ & $\begin{array}{c}\text { Mean of DBP** } \\
\text { (mmHg) }\end{array}$ & p & $\begin{array}{c}\text { Mean of PR\# } \\
\text { (time/minute) }\end{array}$ & p \\
\hline High Midnight Prayer & $9.94(-10-24)$ & 0.626 & $7.00 \pm 7.950$ & 0.939 & $2.31 \pm 6.887$ & 0.215 \\
Low Midnight Prayer & $10.36(-7-30)$ & & $7.81 \pm 7.804$ & & $6.11 \pm 7.383$ & \\
Non- Midnight Prayer & $12.75(4-32)$ & & $7.75 \pm 7.532$ & & $5.50 \pm 7.118$ & \\
\hline Non ${ }^{*}$ (2BP $=$ Sys & & & & &
\end{tabular}

Note: ${ }^{*}$ SBP $=$ Systolic Blood Pressure, ${ }^{* *}$ DBP = Diastolic Blood Pressure, \#PR = Pulse Rate

Table 4 Blood Pressure and Pulse Rate Duration of Recovery

\begin{tabular}{lcccc}
\hline & $\begin{array}{c}\text { Median Time of Blood Pressure } \\
\text { (minute) }\end{array}$ & p & $\begin{array}{c}\text { Mean Time of Pulse Rate } \\
\text { (minute) }\end{array}$ & p \\
\hline High Midnight Prayer & $6.38(6-8)$ & 0.548 & $6.69 \pm 0.946$ & 0.673 \\
Low Midnight Prayer & $6.72(6-11)$ & & $7.03 \pm 1.341$ & \\
Non-midnight Prayer & $6.75(6-11)$ & & $7.00 \pm 1.506$ & \\
\hline
\end{tabular}


95\% Confidence interval, 3.31-6.83) also showed no significant difference (Table 3). Recovery duration of blood pressure $(\mathrm{p}=0.548$; 95\% Confidence interval, 6.40-6.90) and pulse rate $(\mathrm{p}=0.673$; 95\% Confidence interval, 6.637.25) also showed no significant difference between those 3 groups (Table 4).

\section{Discussions}

One of the most common risk factors of hypertension is stress that can activate sympathetic system leading to increased blood pressure. Stress reduction with trancedental meditation program has given an advantage to condition like hypertension and psychological stress $^{7}$, which is caused bylower blood pressure and pulse rate. The improvement of blood pressure and pulse rate is associated with regularity of trancedental meditation practice. $^{8}$

Eventhough the underlying physiologic pathway of trancedental meditation advantageous on blood pressure was still unclear, the practice showed a a decreasing on sympathetic tones and reducing neurohormonal activity that decreased shear stress on the circulation and reduced heart load. Therefore, blood pressure reactivity decreases, even when obtaining acute behavioral stress. ${ }^{9}$

Contact to cold will lead to increased blood pressure and pulse rate because it activates sympathetic nerve. According to the previous study, trancedental meditation gives effect to improve blood pressure and pulse rate. ${ }^{8}$ Improvement on blood pressure in this study referred to cold pressor test result that interprets as normoreactor or hyperreactor. In theory, midnight prayer has a similar effect with trancedental meditation, although the study still has to be developed.

In this study, the comparation between high midnight prayer group, low midnight prayer group, and non midnight prayer group showed a slight difference even though it did not reach a statistical significance. On the contrary, the other previous study had shown the effect of meditation on developed control over sympathetic function. ${ }^{10}$ Pulse rate in this study also showed unsignificant difference. The result of pulse rate showed a similliarity to the study conducted by Mendhurwar and Gadakari. ${ }^{11}$ This unsignificant difference could be caused bythe limitation of this study. History of midnight prayer on the last one month taken by quessionaire, was not recorded every after the participant had performed midnight prayer. Therefore, it could arise recall bias.

This study does not prove the effect of midnight prayer on sympathetic tone. Blood pressure and pulse rate result of this study among those three groups shows no significant difference. Therefore, additional study with more frequent and longer period of midnight prayer should be conducted, because the other previous study which reported the reduction on blood pressure and pulse rate was done in a person practicing transcendental meditation for a long time ${ }^{11}$ Midnight prayer probably has no short term effect, but has long term effect similar to transcendental meditation.

\section{References}

1. World Health Organization. Raised blood pressure. 2013 [cited 2013 April 22]; Available from: http://www.who.int/ gho/ncd/risk_factors/blood_pressure_ prevalence_text/en/.

2. Badan Penelitian dan Pengembangan Kesehatan Departemen Kesehatan Republik Indonesia. Laporan nasional riset kesehatan dasar 2007. Jakarta: Badan Penelitian dan Pengembangan Kesehatan Departemen Kesehatan Republik Indonesia; 2008.

3. Guyton AC, Hall JE. Textbook of medical physiology. 11th ed. Philadelphia: Elsevier Saunders; 2006. p. 758.

4. Ibrahim BS. Spiritual medicine in the history of islamic medicine. J Int Soc History Islamic Med. 2003;2:45 ? 9.

5. Ritesh M, Karia. Blood pressure response to cold pressure test in normal young healthy subjects: a prediction of future possibilities of hypertension. J Phys Pharm Adv. 2012;2(6):223-6.

6. Pramanik T, Regmi P, Adhikari P, Roychowdhury P. Cold pressor test as a predictor of hypertension. J Teh Univ Heart Ctr. 2009;3:177-80.

7. Schneider RH, Grim CE, Rainforth MV, Kotchen T, Nidich SI, GaylordKing C, et al. Stress reduction in the secondary prevention of cardiovascular disease: randomized, controlled trial of transcendental meditation and health education in blacks. Circ Cardiovasc Qual Outcomes. 2012;5:750-8.

8. Anderson JW, Liu C, Kryscio RJ. Blood pressure response to transcendental meditation a meta-analysis. Am J Hypertens. 2008;21:310-6.

9. Barnes VA, Treiber FA, Johnson MH. Impact of transcendental meditation on 
ambulatory blood pressure in africanamerican adolescents. Am J Hypertens. 2004;17(4):366-9.

10. Deepak D, Sinha AN, Gusain VS, Goel A. A Study on effects of meditation on sympathetic nervous system functional status in meditators. J Clin Diagn Res. 2012;6(6):938-42.

11. Mendhurwar SS, Gadakari JG. Effect of transcendental meditation on pulse rate and blood pressure. Int J of Medi and Clin Res. 2012;3(1):107-9. 